\title{
Regulation of $\mathrm{GH}_{3}$-cell function via adenosine $A_{1}$ receptors
}

\author{
Inhibition of prolactin release, cyclic AMP production and inositol phosphate generation
}

\author{
Thérèse M. DELAHUNTY,* Michael J. CRONIN $† \ddagger$ and Joel LINDEN $† \S$ \\ *Department of Neuroscience and †Department of Physiology and Internal Medicine (Cardiology), University of Virginia School \\ of Medicine, Charlottesville, VA 22908, U.S.A.
}

\begin{abstract}
We examined the mechanism by which adenosine inhibits prolactin secretion from $\mathrm{GH}_{3}$ cells, a rat pituitary tumour line. Prolactin release is enhanced by vasoactive intestinal peptide (VIP), which increases cyclic AMP, and by thyrotropin-releasing hormone (TRH), which increases inositol phosphates $\left(\right.$ IP $\left._{x}\right)$. Analogues of adenosine decreased prolactin release, VIP-stimulated cyclic AMP accumulation and TRH-stimulated inositol phospholipid hydrolysis and $\mathrm{IP}_{x}$ generation. Inhibition of Ins $P_{3}$ production by $R$ - $N^{6}$-phenylisopropyladenosine ( $R$-PIA) was rapid $(15 \mathrm{~s})$ and was not affected by the addition of forskolin or the removal of external $\mathrm{Ca}^{2+}$. Addition of adenosine deaminase or the potent adenosine-receptor antagonist, BW-A1433U, enhanced the accumulation of cyclic AMP by VIP, indicating that endogenously produced adenosine tonically inhibits adenylate cyclase. The potency order of adenosine analogues for inhibition of cyclic AMP and $\mathrm{IP}_{x}$ responses (measured in the presence of adenosine deaminase) was $N^{6}$-cyclopentyladenosine $>R$-PIA $>5^{\prime}$ - $N$-ethylcarboxamidoadenosine. This rank order indicates that inhibitions of both cyclic AMP and Ins $P_{3}$ production are mediated by adenosine $\mathrm{A}_{1}$ receptors. Responses to $R$-PIA were blocked by BW-A1433U $(1 \mu \mathrm{M})$ or by pretreatment of cells with pertussis toxin. A greater amount of toxin was required to eliminate the effect of $R$-PIA on inositol phosphate than on cyclic AMP accumulation. These data indicate that adenosine, in addition to inhibiting cyclic AMP accumulation, decreases $\mathrm{IP}_{x}$ production in $\mathrm{GH}_{3}$ cells, possibly by directly inhibiting phosphoinositide hydrolysis.
\end{abstract}

\section{INTRODUCTION}

A number of receptor-mediated biological actions of adenosine have been recognized (reviewed by Williams, 1987). Since the discovery of adenosine receptors in brain (Sattin \& Rall, 1970), it has been determined that adenosine inhibits neurotransmitter release by binding to presynaptic $A_{1}$ receptors (Phillis \& Wu, 1981; Gustaffson et al., 1983; Dunwiddie et al., 1986). Adenosine also has been reported to inhibit peptide-hormone secretion and cyclic AMP accumulation in $\mathrm{GH}_{4} \mathrm{Cl}$ cells (Dorflinger \& Schonbrunn, 1985). $\mathrm{GH}_{4} \mathrm{Cl}$ and $\mathrm{GH}_{3}$ cells are clonal rat pituitary tumour lines which synthesize and release prolactin and growth hormone.

Adenosine in various tissues has been shown to inhibit and to stimulate adenylate cyclase via $A_{1}$ and $A_{2}$ receptors, respectively (Van Calker et al., 1979; Londos et al., 1980). Receptor subtypes can also be distinguished by a difference in the potency order of various agonists (Londos et al., 1980; Wolff et al., 1981). Adenosinemediated inhibition of cerebellar glutamate release through an $A_{1}$ receptor is prevented by pretreating the tissue with pertussis toxin (PTX) (Dolphin \& Prestwich, 1985). This bacterial toxin ADP-ribosylates an inhibitory guanine nucleotide-binding $(G)$ protein, $G_{i}$, and prevents coupling of receptors to adenylate cyclase (Murayama \& Ui, 1983). Despite the clear involvement of cyclic AMP in many responses, adenosine may produce some of its actions independently of the cyclic nucleotide (Stone, 1985). For instance, in dorsal root ganglion cells adenosine inhibits $\mathrm{Ca}^{2+}$ currents directly via a $\mathrm{G}$ protein (Scott \& Dolphin, 1987). Adenosine and its analogues can potentiate histamine-stimulated inositol phosphate accumulation in guinea-pig cortex (Hollingsworth et al., 1986; Hill \& Kendall, 1987) and inhibit the phosphoinositide (PI) pathway in frog paravertebral ganglia (Rubio \& Bencherif, 1987), mouse cerebellum (Hill \& Kendall, 1988), rat striatum (Petcoff \& Cooper, 1987), rat aorta (Long \& Stone, 1987) and rat adipocytes (Schimmel, 1986). Inhibition of the PI pathway has been implicated as a regulatory mechanism of agents other than adenosine. In hippocampal neurons, acidic amino acids inhibit carbachol- and histamine-stimulated inositol phosphate formation (Baudry et al., 1986). In pituitary, dopamine was reported to inhibit angiotensin IIstimulated inositol phosphate generation and hormonal secretion (Enjalbert et al., 1986), but in a later study no effect of dopamine on inositol phosphate generation could be demonstrated (Canonico et al., 1986).

The present study was undertaken to investigate the

Abbreviations used: VIP, vasoactive intestinal peptide; TRH, thyrotropin-releasing hormone (thyroliberin); $R$-PIA, $R$ - $N^{6}$-phenylisopropyladenosine; NECA, $5^{\prime}-N$-ethylcarboxamidoadenosine; CPA, $N^{6}$-cyclopentyladenosine; ADA, adenosine deaminase; EHNA, erythro-9(2-hydroxy-3-nonyl)adenine; PTX, pertussis toxin; PtdIns, phosphatidylinositol; PtdIns4P, phosphatidylinositol 4-phosphate; PtdIns(4,5) $P_{2}$, phosphatidylinositol 4,5-bisphosphate; Ins $P_{3}$, inositol trisphosphate; Ins $P_{2}$, inositol bisphosphate; Ins $P$, inositol monophosphate; IP ${ }_{x}$, the sum of Ins $P$, Ins $P_{2}$ and Ins $P_{3} ; \mathrm{PI}$, phosphoinositide.

$\ddagger$ Present address: Division of Pharmacology, Genentech, 460 Pt. San Bruno Blvd., S. San Francisco, CA 94080, U.S.A.

$\S$ To whom correspondence and reprint requests should be addressed: Box 449, University of Virginia School of Medicine, Charlottesville, VA 22908, U.S.A. 
mechanisms by which adenosine inhibits prolactin release from $\mathrm{GH}_{3}$ cells. These cells maintain many responses of the normal mammotroph in culture and have the advantage of being a more homologous group of cells (Gourdji et al., 1982). Prolactin release from $\mathrm{GH}_{3}$ cells is enhanced by VIP, which increases cyclic AMP (Gourdji et al., 1979), and by TRH, which stimulates the PI pathway (Martin, 1983). Adenosine inhibits prolactin secretion stimulated by either VIP or TRH (Dorflinger \& Schonbrunn, 1985), but the mechanism of inhibition of both these secretory processes was unknown. Our results indicate that adenosine, via $A_{1}$ receptors and PTXsensitive pathways, can decrease intracellular concentrations of cyclic AMP and inositol phosphates.

\section{MATERIALS AND METHODS}

\section{Materials}

Cell culture media, sera and antibiotics were from GIBCO (Grand Island, NY, U.S.A.). Drugs and other materials were from the following sources: VIP and TRH, Peninsula Laboratories (San Carlos, CA, U.S.A.); forskolin, Calbiochem (La Jolla, CA, U.S.A.); R-PIA and ADA, Boehringer Mannheim (Mannheim, Germany); adenosine, Aldrich Chemicals (Milwaukee, WI, U.S.A.); NECA, Warner Lambert (Ann Arbor, MI, U.S.A.); CPA, Research Biochemicals Inc. (Natick, MA, U.S.A.); EHNA, Burroughs Wellcome (Research Triangle Park, NC, U.S.A.); $m y o-\left[{ }^{3} \mathrm{H}\right]$ inositol, New England Nuclear (Boston, MA, U.S.A.); Dowex 1-X8 (formate form), Bio-Rad (Richmond, CA, U.S.A.); bovine serum albumin (fraction V), Sigma (St. Louis, MO, U.S.A.). The following were generously given: BW-A1433U, from Dr. S. Daluge, Burroughs Wellcome; Ro7-2956, from Dr. P. F. Sorter, Hoffman-LaRoche (Nutley, NJ, U.S.A.); maitotoxin, from Dr. T. Yasumoto, Tohuko University, Japan; PTX, from Dr. Eric Hewlett, University of Virginia; $\left[{ }^{3} \mathrm{H}\right]$ inositol phosphates (Ins $P$, Ins $P_{2}$ and Ins $P_{3}$ ) from Dr. James Garrison, University of Virginia. Reagents for the prolactin radioimmunoassay, obtained from the National Hormone and Pituitary Program, were from Dr. Michael Thorner, University of Virginia.

\section{Methods}

Cell culture. $\mathrm{GH}_{3}$ cells were grown in tissue-culture flasks in Ham's F-10 medium with $15 \%(\mathrm{v} / \mathrm{v})$ horse serum and $2.5 \%(\mathrm{v} / \mathrm{v})$ fetal-calf serum at $37^{\circ} \mathrm{C}$ in air/ $\mathrm{CO}_{2}$ (19:1). The medium was changed three times a week and the cells were passaged every 2 weeks. Cells were detached with 1 mM-EGTA, counted with a Coulter counter, and plated on Falcon Primaria 24-well plates at a density of $1 \times 10^{5}$ cells/well. Experiments were performed 1 week later, at which time the cell density was $(2.5-3) \times 10^{5}$ cells per well.

Prolactin release and cyclic AMP accumulation. Cells were washed for $30 \mathrm{~min}$ with serum- and bicarbonatefree RPMI medium containing $20 \mathrm{~mm}-\mathrm{NaHepes,} \mathrm{pH} 7.4$, at $37^{\circ} \mathrm{C}$ before the application of drugs, which were made up in the same medium. To determine basal cyclic AMP accumulation, cells were incubated with $1 \mathrm{~mm}$-Ro 7-2956, a phosphodiesterase inhibitor which does not act as an antagonist at adenosine receptors (Linden et al., 1982). The cyclic AMP, extracted from cells with $0.1 \mathrm{M}-$ $\mathrm{HCl}$, was acetylated and assayed by automated radio- immunoassay (Brooker et al., 1976). Prolactin released into the tissue-culture medium was collected after a 30 min incubation at $37^{\circ} \mathrm{C}$ and assayed by radioimmunoassay. Pretreatment of cells with $50 \mathrm{ng}$ of PTX/ $\mathrm{ml}$ for $6 \mathrm{~h}$ was sufficient to block completely the effect of adenosine on cyclic AMP accumulation.

Extraction and assay of inositol phosphates. $\mathrm{GH}_{3}$ cells were incubated in serum-free Ham's F-10 medium with $0.1 \%$ bovine serum albumin and $1 \mu \mathrm{Ci}$ of $m y o-\left[{ }^{3} \mathrm{H}\right]-$ inositol $/ \mathrm{ml}$ at $37^{\circ} \mathrm{C}$ for $48 \mathrm{~h}$. Longer incubation did not significantly increase incorporation of label into phospholipids (results not shown). The incubation medium was removed and cells were rapidly washed twice with Krebs bicarbonate-buffered medium (Krebs \& Henseleit, 1932) at $37^{\circ} \mathrm{C}, \mathrm{pH} \mathrm{7.4,} \mathrm{containing} 119 \mathrm{~mm}$ $\mathrm{NaCl}, 4 \mathrm{~mm}-\mathrm{KCl}, 1 \mathrm{~mm}-\mathrm{KH}_{2} \mathrm{PO}_{4}, 2 \mathrm{~mm}-\mathrm{MgSO}_{4}, 2 \mathrm{~mm}-$ $\mathrm{CaCl}_{2}, 10 \mathrm{~mm}-\mathrm{NaHCO}_{3}, 5 \mathrm{~mm}-\mathrm{NaHepes}, 0.2 \%$ glucose and $0.1 \%$ bovine serum albumin. Drugs were made up and applied in $\mathrm{Krebs}$ medium with $10 \mathrm{~mm}-\mathrm{LiCl}$. In some experiments $1 \mathrm{mM}$-EGTA was added to $\mathrm{Ca}^{2+}$-free $\mathrm{Krebs}$ medium and applied to cells. Reactions were terminated by adding $0.5 \mathrm{M}-\mathrm{HClO}_{4}$ with $5 \mathrm{~mm}$-EDTA and $1 \mathrm{~mm}-$ diethylenetriaminepenta-acetic acid to prevent the precipitation of $\mathrm{Mg}^{2+}$ salts of the inositol phosphates. Plates were kept on ice for $30 \mathrm{~min}$, and then cell extracts were transferred to centrifuge tubes containing sufficient $\mathrm{K}_{2} \mathrm{CO}_{3}(5 \mathrm{M})$ to raise the $\mathrm{pH}$ to $8-9$. Protein and perchlorate precipitates were pelleted by centrifugation, and the supernatants were applied to Dowex AG 1X8 (formate form) anion-exchange columns and eluted as described by Berridge et al. (1983). An elution profile with tritiated standards was performed to verify separation. Quantification of $\left[{ }^{3} \mathrm{H}\right]$ inositol phosphates recovered was performed by liquid-scintillation spectrometry and corrected for quenching. For both cyclic AMP and IP ${ }_{x}$, each value represents the mean of four determinations, and each experiment was repeated independently at least twice.

Extraction and separation of $m y o-\left[{ }^{3} \mathrm{H}\right]$ inositol-labelled phosphoinositides. $\mathrm{GH}_{3}$ cells were labelled to equilibrium by incubating them for $48 \mathrm{~h}$ in inositol-free Ham's F10 medium supplemented with dialysed serum to which myo- $\left[{ }^{3} \mathrm{H}\right]$ inositol $(1 \mu \mathrm{Ci} / \mathrm{ml})$ was added. Cells were detached with EGTA and washed, and then added to test tubes in $90 \mu \mathrm{l}$ portions of $5 \times 10^{5}$ cells per tube. Phosphoinositides were extracted and separated by the method of Martin (1986). Reactions were terminated by adding chloroform $/$ methanol $/ \mathrm{HCl}(10: 10: 1$, by vol.). Separation into two phases was promoted by adding $0.25 \mathrm{ml}$ of $10 \mathrm{~mm}$-EDTA and $0.1 \mathrm{~mm}$-sodium orthovanadate. The organic phase was washed twice with $0.1 \mathrm{M}-\mathrm{KCl} / \mathrm{methanol}(1: 1, \mathrm{v} / \mathrm{v})$ and dried under a stream of $\mathrm{N}_{2}$. Lipids were deacylated by incubation for $20 \mathrm{~min}$ at room temperature in $1 \mathrm{ml}$ of chloroform, $0.2 \mathrm{ml}$ of methanol and $0.2 \mathrm{ml}$ of $1 \mathrm{M}-\mathrm{KOH}$ (in methanol/water, $19: 1, \mathrm{v} / \mathrm{v})$. the reaction was stopped by adding $1 \mathrm{ml}$ of chloroform, $0.6 \mathrm{ml}$ of methanol and $0.6 \mathrm{ml}$ of water. After phase separation the aqueous phase was removed and diluted with $6 \mathrm{ml}$ of $6 \mathrm{~mm}-\mathrm{Na}_{2} \mathrm{~B}_{4} \mathrm{O}_{7}$ and applied to Dowex AG 1X8 columns (formate form). Sequential washes eluted the glycerophospholipids as follows: $5 \mathrm{mM}-$ $\mathrm{Na}_{2} \mathrm{~B}_{4} \mathrm{O}_{7} / 0.18 \mathrm{M}$-ammonium formate, glycerophosphoinositol; $0.5 \mathrm{M}$-ammonium formate $/ 0.1 \mathrm{M}$-formic acid, glycerophosphoinositol phosphate; $1 \mathrm{M}$-ammonium 
Table 1. Effect of $\boldsymbol{R}$-PIA on prolactin release from $\mathbf{G H}_{3}$ cells

Cells were incubated for $30 \mathrm{~min}$ in medium alone, $100 \mathrm{nM}$ VIP or $100 \mathrm{nM}-\mathrm{TRH}$ in the absence and presence of $10 \mu \mathrm{M}$ $R$-PIA alone, or with $1 \mu \mathrm{M}$-BW-A1433U. All incubations were carried out in the presence of ADA (1 unit $/ \mathrm{ml})$. Each point represents the mean \pm S.E.M. for 12 wells assayed in duplicate: $*$ significant decrease $(P<0.01)$ compared with the other two groups.

\begin{tabular}{llrr}
\hline & \multicolumn{3}{c}{ Prolactin released $(\mathrm{ng} / \mathrm{ml})$} \\
\cline { 2 - 4 } & Basal & VIP & TRH \\
\hline Control & $76 \pm 8$ & $151 \pm 15$ & $127 \pm 9$ \\
$R$-PIA & & & \\
$R$-PIA + BW-A1433U & $84 \pm 8$ & $191 \pm 22$ & $144 \pm 22$ \\
& & & \\
\hline
\end{tabular}

formate/0.1 M-formic acid, glycerophosphoinositol bisphosphate. The separated lipids were quantified by liquid-scintillation spectrometry of the eluted fractions.

\section{Data analysis}

$\mathrm{ED}_{50}$ concentrations were calculated by Marquadt's (1963) least-squares non-linear regression, as modified by Tabata \& Ito (1975), to the equation:

$$
R=B+(M-B)[D] /\left(\mathrm{ED}_{50}+[D]\right)
$$

where $[D]=$ drug concentration, $R=$ response, $B=$ basal value and $M=$ maximum response. Statistical significance was determined by analysis of variance and Duncan's multiple-range or Newman-Keuls tests.

\section{RESULTS}

\section{Release of prolactin from $\mathbf{G H}_{3}$ cells is inhibited by adenosine}

$\mathrm{GH}_{3}$ cells secrete prolactin continually into the surrounding medium. The addition of $10 \mu \mathrm{M}-R$-PIA decreased the basal rate of secretion by $44 \%$. The secretagogues VIP and TRH enhanced prolactin release by $100 \%$ and $66 \%$ above control values $(P<0.01)$ respectively. The stimulatory effects of both of these hormones were decreased by more than $50 \%$ in the presence of $10 \mu \mathrm{M}$ - $R$-PIA (Table 1). The adenosine $\mathrm{A}_{1}$-receptor antagonist BW-A1433U at a concentration of $1 \mu \mathrm{M}$, which has no effect on cyclic AMP phosphodiesterase activity (Daluge \& Leighton, 1986; Clemo et al., 1987), completely blocked the effects of $R$-PIA, confirming that its actions are mediated by adenosine receptors.

\section{Adenosine and cyclic AMP accumulation}

Adenosine and its analogues inhibited basal, forskolinand VIP-stimulated increases in the cyclic AMP content of $\mathrm{GH}_{3}$ cells. The rank order of potency was CPA > $R$-PIA $>$ NECA $>$ adenosine (Table 2), typical of $\mathrm{A}_{1}$ receptors (Wolff et al., 1981). The inhibition of VIPstimulated cyclic AMP accumulation by $10 \mu \mathrm{M}-R$-PIA was abolished by $1 \mu \mathrm{M}-\mathrm{BW}-\mathrm{A} 1433 \mathrm{U}$ (Table 3 ), or by pretreatment of cells with PTX $(50 \mathrm{ng} / \mathrm{ml})$ for $6 \mathrm{~h}$ (results not shown) and for $24 \mathrm{~h}$ (Table 4). Adenosine or its analogues did not induce an increase in cyclic AMP content in cells pretreated with PTX, suggesting that these cells do not contain stimulatory adenosine $A_{2}$ receptors linked to adenylate cyclase. In the absence of
Table 2. Inhibition of VIP-stimulated cyclic AMP accumulation by adenosine and its analogues

Adenosine, $R$-PIA and NECA effects on cyclic AMP accumulation produced by VIP $(100 \mathrm{nM})$ were evaluated by using eight concentrations in the range $10 \mathrm{pM}-0.1 \mathrm{mM}$. Cells were incubated for $5 \mathrm{~min}$ in the presence of 3 units of $\mathrm{ADA} / \mathrm{ml}$ (except for adenosine). Identical potency orders were obtained in two additional experiments. All $\mathrm{ED}_{50}$ values differed significantly from each other $(P<0.01)$. Maximal inhibition was defined as the percentage decrease in the VIP-stimulated response by $100 \mu \mathrm{M}$ of each agonist. Results are means \pm S.E.M.

\begin{tabular}{lcc} 
Drug & $\mathrm{ED}_{50}(\mathrm{nM})$ & Maximal inhibition (\%) \\
\hline CPA & $0.4 \pm 0.1$ & $84.0 \pm 3.0$ \\
$R$-PIA & $12.0 \pm 4.0$ & $81.0 \pm 7.0$ \\
NECA & $48.0 \pm 9.0$ & $86.0 \pm 10.0$ \\
Adenosine & $74.0 \pm 10.0$ & $80.0 \pm 2.0$ \\
\hline
\end{tabular}

ADA, cyclic AMP accumulation in response to VIP alone was enhanced 2-fold by PTX, and the toxin alone also caused a 3-fold increase in basal cyclic AMP (Table 4). ADA and BW-A1433U also elevated basal and VIPstimulated cyclic AMP accumulation, suggesting that endogenous adenosine is released by $\mathrm{GH}_{3}$ cells in quantities sufficient to activate partially $A_{1}$ receptors (Fig. 1). Basal cyclic AMP contents increased from 11.6 to $15.8 \mathrm{pmol} /$ well in the presence of ADA (1 unit/ml) $(P<0.001)$, but the maximal effect of the enzyme required in excess of 3 units $/ \mathrm{ml}$. Both the efficacy and the potency of VIP were significantly enhanced by both ADA and BW-A1433U (Fig. 1).

\section{Adenosine and $I P_{x}$ accumulation}

In order to examine the effects of drugs on PI metabolism, it was desirable to achieve a constant specific radioactivity of the radioactive inositol incorporated into lipids. Then changes in inositol phospholipid contents could be directly monitored by measuring the radioactive content of phosphoinositides and inositol phosphates. In the course of this study, $\mathrm{GH}_{3}$ cells were labelled to equilibrium in all experiments. The addition of $10 \mu$ M-adenosine or - $R$-PIA decreased the IP ${ }_{x}$ accumulation after a $10 \mathrm{~min}$ incubation with $100 \mathrm{nM}$-TRH in the presence of $10 \mathrm{~mm}-\mathrm{LiCl}$ by $60-65 \%(P<0.0001$; data pooled from six experiments consisting of four replicates with each drug). This inhibition was abolished by $1 \mu \mathrm{M}$ BW-A1433U (Table 3). No significant effect of BWA1433U or ADA alone on basal or TRH-stimulated IP $_{x}$ accumulation could be demonstrated, suggesting little or no role for endogenous adenosine in the regulation of $\mathrm{IP}_{x}$ production. In some experiments $R$-PIA was found to decrease significantly basal IP $_{x}$ production (Table 5). $\mathrm{Li}^{+}$impedes breakdown of inositol sugars to free inositol (Drummond et al., 1984). In the presence of $\mathrm{LiCl}$, basal $\mathrm{IP}_{x}$ accumulation and TRHstimulated IP $P_{x}$ accumulation were linear with time up to $10 \mathrm{~min}$. $R$-PIA also inhibited $\mathrm{IP}_{x}$ accumulation in the absence of $\mathrm{LiCl}$ (results not shown), indicating that $R$-PIA does not act by interfering with the action of $\mathrm{LiCl}$. Adenosine and its analogues had no effect on the elution of $\left[{ }^{3} \mathrm{H}\right] \mathrm{IP}{ }_{x}$ standards from the Dowex columns (results not shown). 
Table 3. Effect of various drugs on the IP ${ }_{x}$ and cyclic AMP content of $\mathbf{G H}_{3}$ cells

Drugs (100 nM-VIP, $100 \mathrm{nM}$-TRH, $10 \mu \mathrm{M}$-R-PIA, $10 \mu \mathrm{M}$-adenosine, $1 \mu \mathrm{M}$-carbachol, $100 \mathrm{nM}$-somatostatin and $1 \mu \mathrm{M}$-forskolin) were made up in buffer with 3 units of $\mathrm{ADA} / \mathrm{ml}$ (except adenosine). For IP ${ }_{x}$ determinations, $10 \mathrm{mM}-\mathrm{LiCl}$ was included. Results are means \pm S.E.M. for the numbers of replicates indicated in parentheses; ${ }^{*}$ inhibition significant compared with respective control $(P<0.01)$; ND, not determined.

\begin{tabular}{|c|c|c|}
\hline & $\begin{array}{l}{\left[{ }^{3} \mathrm{H}\right] \text { Inositol }} \\
\text { phosphates } \\
\text { (c.p.m./well) }\end{array}$ & $\begin{array}{c}\text { Cyclic } \\
\text { AMP } \\
\text { (pmol/well) }\end{array}$ \\
\hline $\begin{array}{l}\text { Basal } \\
\text { TRH } \\
\text { TRH + } R \text {-PIA } \\
\text { TRH + adenosine } \\
\text { TRH + adenosine + BW-A1433U } \\
\text { TRH + forskolin } \\
\text { TRH + } R \text {-PIA + forskolin }\end{array}$ & $\begin{array}{l}144 \pm 7 \\
825 \pm 34 \quad(24) \\
471 \pm 13^{*}(24) \\
493 \pm 17^{*}(12) \\
810 \pm 42 \quad(12) \\
820 \pm 36 \quad(8) \\
474 \pm 15^{*}\end{array}$ & $\begin{array}{l}\text { ND } \\
\text { ND } \\
\text { ND } \\
\text { ND } \\
\text { ND } \\
\text { ND } \\
\text { ND }\end{array}$ \\
\hline $\begin{array}{l}\text { Basal } \\
\text { TRH } \\
\text { TRH + somatostatin } \\
\text { TRH + carbachol }\end{array}$ & $\begin{array}{ll}109 \pm 13 & (8) \\
716 \pm 33 & (8) \\
715 \pm 1 & (8) \\
748 \pm 29 & (8)\end{array}$ & $\begin{array}{l}\text { ND } \\
\text { ND } \\
\text { ND } \\
\text { ND }\end{array}$ \\
\hline $\begin{array}{l}\text { Basal } \\
\text { Forskolin } \\
\text { Forskolin + } R \text {-PIA } \\
\text { VIP } \\
\text { VIP + } R \text {-PIA } \\
\text { VIP + } R \text {-PIA + BW-A1433U } \\
\text { VIP + somatostatin } \\
\text { VIP + carbachol }\end{array}$ & $\begin{array}{l}\text { ND } \\
\text { ND } \\
\text { ND } \\
\text { ND } \\
\text { ND } \\
\text { ND } \\
\text { ND }\end{array}$ & $\begin{array}{l}4.0 \pm 0.1(9) \\
322 \pm 10(9) \\
148 \pm 4^{*}(9) \\
80 \pm 4 \quad(9) \\
36 \pm 3^{*}(9) \\
85 \pm 3 \quad(9) \\
59 \pm 1^{*}(9) \\
66 \pm 2^{*}(9)\end{array}$ \\
\hline
\end{tabular}

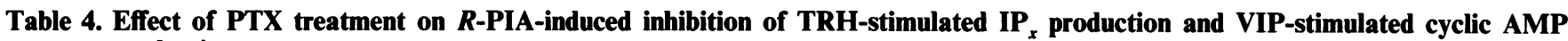
production

Cells were pretreated with the toxin for $24 \mathrm{~h}$. Results represent means \pm S.E.M. for four values from two or more independent experiments; * indicates significant inhibition by $R$-PIA $(P<0.01)$; ND, not determined.

\begin{tabular}{|c|c|c|c|c|}
\hline & & \multicolumn{3}{|c|}{ Concn. of PTX } \\
\hline & & $\mathbf{0}$ & $50 \mathrm{ng} / \mathrm{ml}$ & $100 \mathrm{ng} / \mathrm{ml}$ \\
\hline$\left[{ }^{3} \mathrm{H}\right] \mathrm{IP} \mathrm{P}_{x}$ (c.p.m./well) & $\begin{array}{l}\text { Basal } \\
\text { TRH } \\
\text { TRH + R-PIA }\end{array}$ & $\begin{array}{l}144 \pm 7 \\
825 \pm 34 \\
471 \pm 13^{*}\end{array}$ & $\begin{array}{l}145 \pm 5 \\
836 \pm 33 \\
579 \pm 20^{*}\end{array}$ & $\begin{array}{l}123 \pm 8 \\
745 \pm 35 \\
739 \pm 35\end{array}$ \\
\hline Cyclic AMP (pmol/well) & $\begin{array}{l}\text { Basal } \\
\text { VIP } \\
\text { VIP }+R \text {-PIA }\end{array}$ & $\begin{array}{c}2 \pm 1 \\
80 \pm 4 \\
36 \pm 3^{*}\end{array}$ & $\begin{array}{r}6 \pm 2 \\
89 \pm 5 \\
83 \pm 5\end{array}$ & $\begin{array}{l}\text { ND } \\
\text { ND } \\
\text { ND }\end{array}$ \\
\hline
\end{tabular}

Since adenosine and its analogues are inhibitors of adenylate cyclase activity in $\mathrm{GH}_{3}$ cells, we considered the possibility that inhibition of PI degradation might be an indirect result of this action. However, the ability of $R$-PIA to inhibit TRH-stimulated IP $_{x}$ accumulation was not changed by addition of $1 \mu \mathrm{M}$-forskolin (Table 3 ). Even in the presence of $1 \mu \mathrm{M}$ - $R$-PIA, forskolin increased cyclic AMP by more than 40 -fold over the basal value. Moreover, carbachol and somatostatin decreased VIPstimulated cyclic AMP accumulation, but had no effect

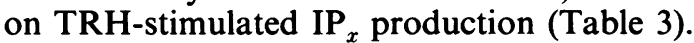

The effect of PTX on adenosine-induced inhibition of TRH-stimulated IP ${ }_{x}$ accumulation was also investigated. Although pretreating cells with PTX $(50 \mathrm{ng} / \mathrm{ml})$ for as little as $6 \mathrm{~h}$ abolished adenosine-mediated effects on cyclic AMP accumulation, such treatment did not remove the inhibitory action of adenosine on IP $_{x}$ production. Increasing the time of incubation to $24 \mathrm{~h}$ had a partial effect, but it was necessary to increase the concentration of PTX to $100 \mathrm{ng} / \mathrm{ml}$ for $24 \mathrm{~h}$ in order to abolish completely the effect of $R$-PIA on IP $_{x}$ accumulation (Table 4). IP ${ }_{x}$ accumulation in response to TRH decreased slightly when cells were pretreated with $100 \mathrm{ng}$ of PTX $/ \mathrm{ml}$ for $24 \mathrm{~h}$, an observation also reported by Martin et al. (1986). This may be a trophic effect, as serum-stimulated proliferation is inhibited in the presence of PTX (Murayama \& Ui, 1987). Additional support for this proposal is the finding that PTX treatment at this concentration decreased basal IP ${ }_{x}$ concentrations by $15 \%$. Incubation with PTX for shorter times at lower 


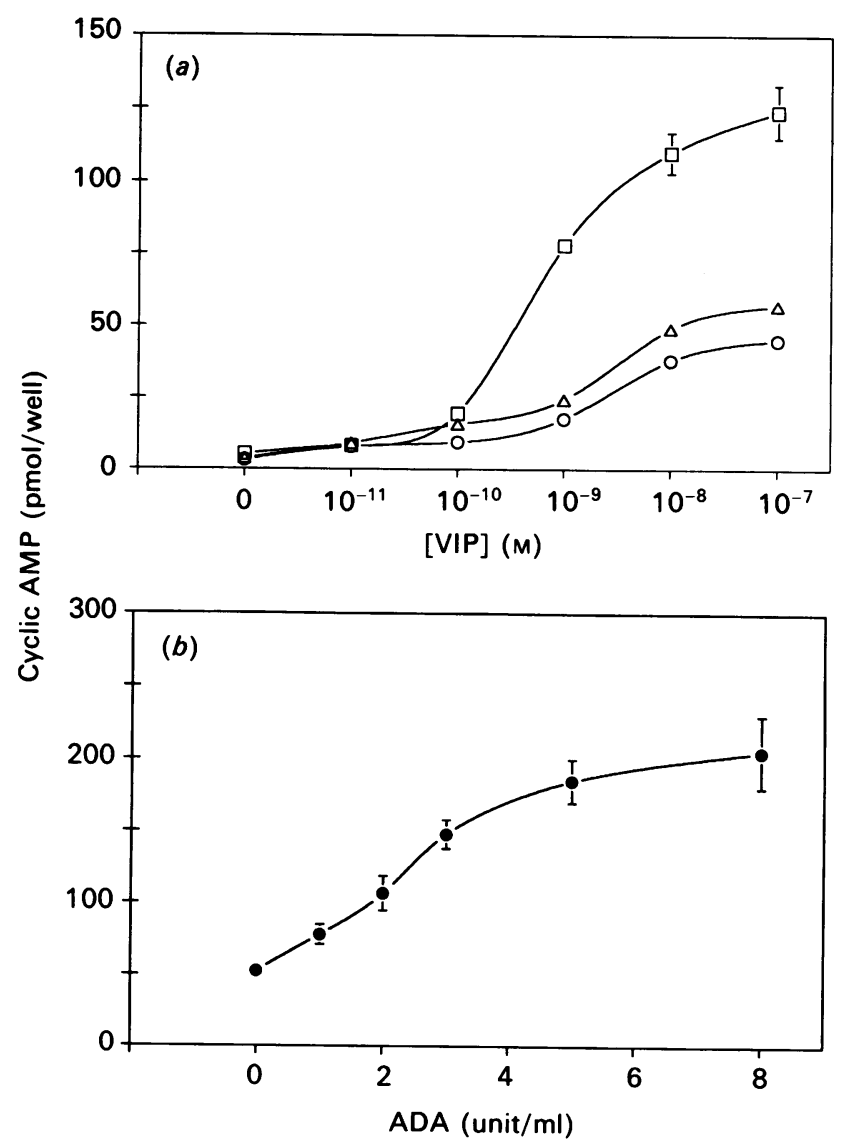

Fig. 1. Effect of BW-A1433U and ADA on VIP-stimulated cyclic AMP accumulation in $\mathbf{G H}_{3}$ cells

(a) VIP dose/response alone $(\mathrm{O})$ and in the presence of 1 unit of $\mathrm{ADA} / \mathrm{ml}(\triangle)$ or $1 \mu \mathrm{M}-\mathrm{BW}-\mathrm{A} 1433 \mathrm{U}(\square)$. In the presence of ADA (1 unit $/ \mathrm{ml})$ the $\mathrm{ED}_{50}$ of VIP decreased from 2.4 to $1.8 \mathrm{nM}$ (not significant) and the maximum stimulation increased by $26 \%(P<0.001)$. In the presence of BW-A1433U the $\mathrm{ED}_{50}$ of VIP decreased to $0.6 \mathrm{nM}$ $(P<0.001)$ and the maximum stimulation increased by $170 \%(P<0.001)$. (b) Effect of ADA on VIP(100 nM)-stimulated cyclic AMP production. Incubations were for $5 \mathrm{~min}$, and each point represents the mean \pm S.E.M. for eight wells assayed in duplicate.

doses did not decrease the $\mathrm{IP}_{x}$ or cyclic AMP responses to TRH and VIP respectively.

The efficacy rather than the potency $\left(\mathrm{ED}_{50} 10 \mathrm{nM}\right)$ of TRH was decreased by $R$-PIA (Fig. 2a). Adenosine analogues inhibited TRH-stimulated IP $_{x}$ generation in a concentration-dependent manner, with the potency order CPA > PIA > NECA (Fig. 2b), identical with that observed for inhibition of VIP-stimulated cyclic AMP accumulation (Table 2). The responses differed, however, in their $\mathrm{IC}_{50}$ values (concn. giving $50 \%$ inhibition) and maximal effects. The $\mathrm{IC}_{50}$ values for inhibition of $\mathrm{IP}_{x}$ generation were higher than for cyclic AMP, and maximal inhibition was achieved in the micromolar range (Fig. $2 b$ ). Increasing drug concentrations further resulted in a lessening of inhibition and produced a $U$-shaped doseresponse curve.

There was a lag of over 2 min before significant inhibition of TRH-stimulated IP ${ }_{x}$ production was observed in the presence of $R$-PIA (Fig. 3). In measuring
Table 5. Effect of $\left[\mathrm{Ca}^{2+}\right]$ on inhibition of $\mathrm{IP}_{x}$ accumulation by R-PIA

Extracellular and intracellular $\mathrm{Ca}^{2+}$ concentrations were manipulated by preincubating cells with EGTA, and by adding $\mathrm{KCl}$ and maitotoxin (MTX; $50 \mathrm{ng} / \mathrm{ml}$ ). Inositol phosphates and cyclic AMP were extracted and measured as described under 'Methods'. Each point represents the mean \pm S.E.M. for 12 wells; * inhibition by $R$-PIA significant compared with respective control $(P<0.01)$; $\dagger$ greater than basal $(P<0.001)$.

$\left[{ }^{3} \mathrm{H}\right]$ Inositol phosphates (c.p.m./well)

$\mathrm{Ca}^{2+}$-free
$1.5 \mathrm{mM}^{-\mathrm{Ca}^{2+}} \quad 140 \mathrm{mM}-\mathrm{KCl}+1 \mathrm{mM}-\mathrm{EGTA}$

\begin{tabular}{llll}
\hline Basal & $186 \pm 12$ & $225 \pm 20$ & $179 \pm 5$ \\
$R$-PIA & $130 \pm 17^{*}$ & $190 \pm 33$ & $153 \pm 9^{*}$ \\
TRH & $895 \pm 19 \dagger$ & $944 \pm 39 \dagger$ & $577 \pm 12 \dagger$ \\
TRH + R-PIA & $453 \pm 18^{*}$ & $619 \pm 19^{*}$ & $386 \pm 17^{*}$ \\
MTX & $595 \pm 35 \dagger$ & - & - \\
MTX + R-PIA & $402 \pm 13^{*}$ & - & - \\
\hline
\end{tabular}

IP $\mathrm{P}_{x}$ formation in $\mathrm{GH}_{3}$ cells, in most experiments we evaluated the sum of all metabolites, as opposed to analysing individual $\mathrm{IP}_{x}$ species. In light of the large 1.umber of inositol phosphate metabolites formed, with variable kinetics, true resolution of cycle dynamics in $\mathrm{GH}_{3}$ cells will require further study. Since production of Ins $P_{3}$ is still considered to precede production of all other metabolites, we examined its appearance over time. In $\mathrm{GH}_{3}$ cells two isomers of Ins $P_{3}$ can be measured by h.p.l.c. TRH-stimulated $\operatorname{Ins}(1,4,5) P_{3}$ accumulation has been shown to reach a peak in $1 \mathrm{~s}$ and to decrease to halfmaximal values in $30 \mathrm{~s}$, whereas $\operatorname{Ins}(1,3,4) P_{3}$ begins to increase by $30 \mathrm{~s}$ and reaches a maximum at 1 min (Dean $\&$ Moyer, 1987). Thus Ins $P_{3}$ measured at early time points should primarily reflect the initial product of PtdIns $(4,5) P_{2}$ hydrolysis, Ins $(1,4,5) P_{3}$. $R$-PIA inhibited Ins $P_{3}$ generation at the earliest time point measured, $15 \mathrm{~s}$.(Fig. 3b), at which time no significant decrease in the sum of all inositol phosphates eluted together could be detected. At times in excess of 1 min, $R$-PIA produced much more pronounced inhibition of $\mathrm{IP}_{x}$ than of $\operatorname{Ins} P_{3}$ production.

We investigated whether the inhibitory effect of adenosine on $\mathrm{IP}_{x}$ accumulation is influenced by the internal and external $\mathrm{Ca}^{2+}$ concentrations $\left(\left[\mathrm{Ca}^{2+}\right]_{\mathrm{b}}\right.$ and $\left.\left[\mathrm{Ca}^{2+}\right]_{0}\right)$. Near-zero $\left[\mathrm{Ca}^{2+}\right]_{0}$ was achieved by preincubating cells in $\mathrm{Ca}^{2+}$-free buffer containing 1 mM-EGTA. Since $\mathrm{GH}_{3}$ cells contain voltage-dependent $\mathrm{Ca}^{2+}$ channels (Dufy et al., 1986; Schlegel et al., 1984), $\left[\mathrm{Ca}^{2+}\right]_{\mathrm{i}}$ was elevated by depolarizing the plasma membrane with $140 \mathrm{~mm}-\mathrm{KCl}$ or by adding maitotoxin, which activates $\mathrm{Ca}^{2+}$ channels (Takahashi et al., 1983) and elevates $\left[\mathrm{Ca}^{2+}\right]_{\mathrm{i}}$ in pituitary cells (Anderson \& Cronin, 1987). The effects of these agents are shown in Table 5. IP production measured in the presence of $\mathrm{KCl}$ and maitotoxin was still significantly decreased by $R$-PIA (Table 5). In cells incubated in $1.5 \mathrm{~mm}-\mathrm{Ca}^{2+}$ or preincubated for 10 min in $\mathrm{Ca}^{2+}$-free buffer containing $1 \mathrm{mM}-$ EGTA, $10 \mu \mathrm{M}$-R-PIA inhibited TRH-stimulated IP $_{x}$ generation by $52 \%(P<0.001)$ and $49 \%(P<0.01)$, respectively. After addition of $140 \mathrm{~mm}-\mathrm{KCl}$, inhibition of 


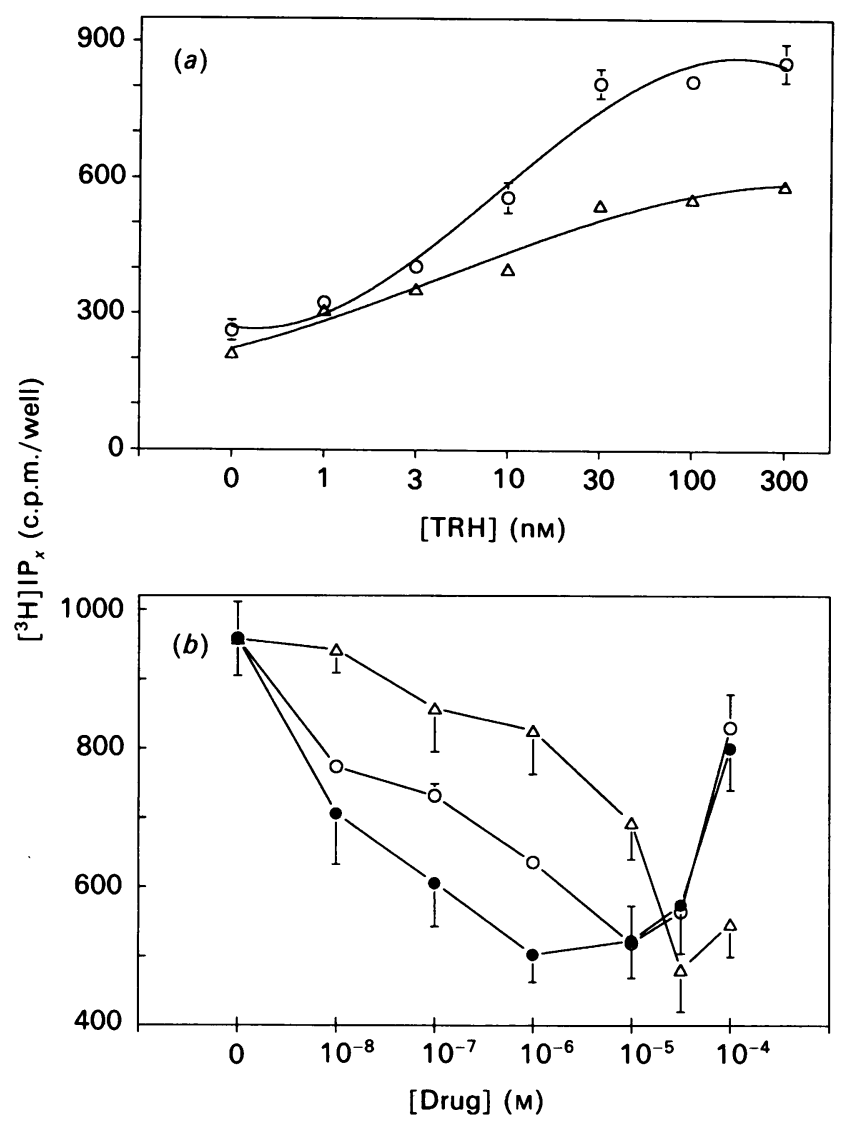

Fig. 2. Dose/response curves for (a) TRH-stimulated IP accumu- $_{x}$ lation in the presence and absence of $10 \mu \mathrm{M}-R$-PIA and (b) for inhibition of TRH-stimulated IP $x$ generation by various adenosine analogues

(a) Results represent means \pm S.E.M. for four determinations. In the presence of $R$-PIA $(\triangle)$ the $E_{50}$ value did not change significantly and the efficacy decreased by $35 \%$ $(P<0.001)$. (b) The $\mathrm{IC}_{50}$ values for inhibition are as follows: CPA (O), $12 \pm 2 \mathrm{nM} ; R$-PIA (O), $19 \pm 9 \mathrm{~nm}$; NECA $(\triangle), 700 \pm 43 \mathrm{nM}$. Each point represents the mean \pm S.E.M. for four wells determined in the presence of $10 \mathrm{~mm}-\mathrm{LiCl}$ and 3 units of ADA/ml. Similar results were obtained in three independent experiments. IP ${ }_{x}$ measurements were as described under 'Methods'.

the TRH response was decreased to $28 \%$, but was still significant $(P<0.005)$ (Table 5). In an additional experiment (results not shown), $\mathrm{KCl}$ produced a significant $(P<0.05)$ increase in basal $\mathrm{IP}_{x}$, as has been previously reported (Biden et al., 1987), but did not significantly change the response to TRH. When cells were pre-exposed to EGTA for $30 \mathrm{~min}$ before application of drugs, the response to TRH was further decreased, but the ability of $R$-PIA to inhibit TRH-stimulated IP $_{x}$ accumulation was not affected (results not shown). Exposure of the cells to EGTA for more than $1 \mathrm{~h}$ abolished the response to TRH [Ins $P_{3}$ accumulation measured after $15 \mathrm{~s}$ in the presence of TRH $(59 \pm 3$ c.p.m.) and TRH $+R$-PIA ( $60 \pm 5$ c.p.m.) did not differ significantly from basal values $(61 \pm 2$ c.p.m. $)$ ]. The effect of a prolonged decrease in $\left[\mathrm{Ca}^{2+}\right]_{i}$ to decrease hormonestimulated IP ${ }_{x}$ generation has been observed in a variety of cell types (Abdel-Latif, 1986).
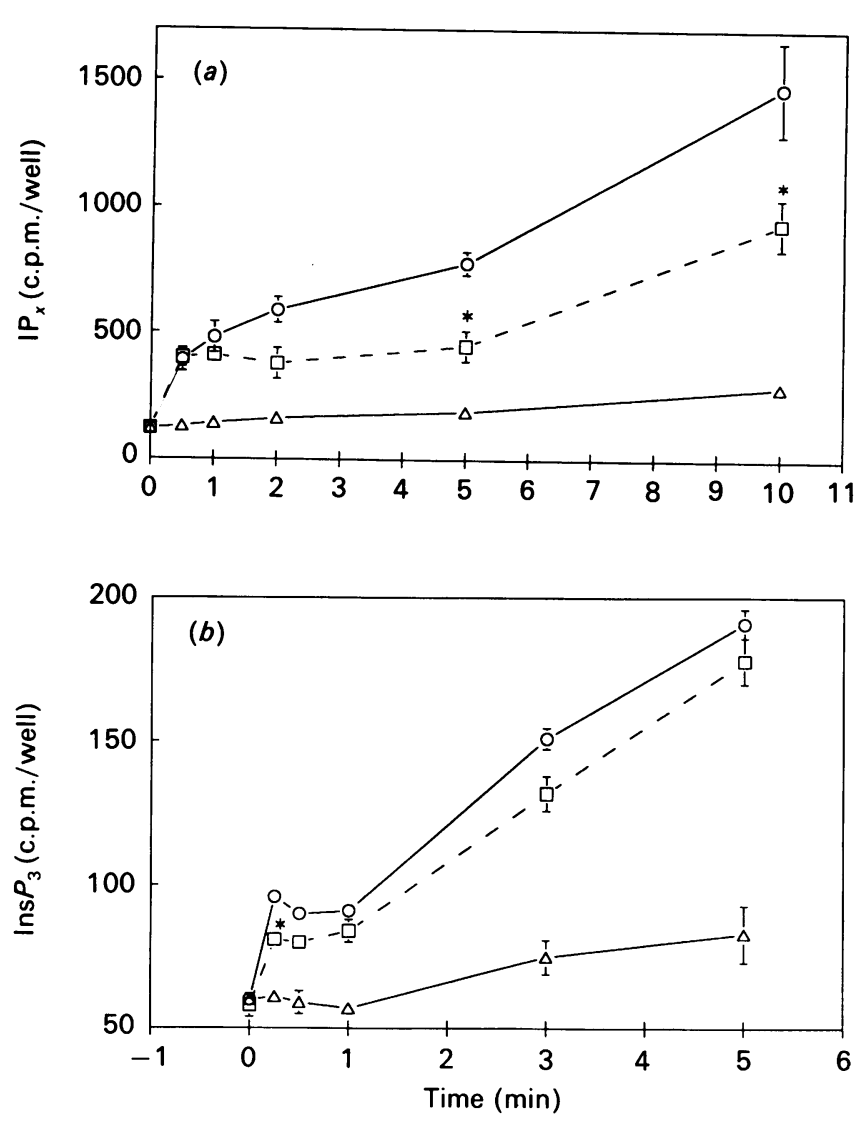

Fig. 3. Effect of $\boldsymbol{R}$-PIA on TRH-stimulated IP ${ }_{x}$ accumulation (a) and $\operatorname{Ins} P_{3}$ production (b)

IP ${ }_{x}$ production was stimulated by $100 \mathrm{nM}-\mathrm{TRH}$ in the presence $(\square)$ or absence $(O)$ of $10 \mu \mathrm{M}$ - $R$-PIA. Each point represents the means \pm S.E.M. for four wells repeated independently three times and measured in the presence of $10 \mathrm{mM}$-LiCl. $R$-PIA had no effect on basal $\mathrm{IP}_{x}$ contents $(\triangle)$. Error bars smaller than the symbols are not shown; * indicates significant inhibition by $R$-PIA $(P<0.01)$.

\section{Effect of $R$-PIA on TRH-stimulated polyphosphoinositide hydrolysis}

TRH caused a modest decrease in PtdIns (Fig. 4a) and a rapid and transient decrease in PtdIns4P (Fig. $4 b$ ) and PtdIns(4,5) $P_{2}$ (Fig. $\left.4 c\right)$. In the presence of $R$-PIA $(10 \mu \mathrm{M})$, the TRH-stimulated hydrolysis of these phospholipids was almost completely prevented (Figs. $4 a, 4 b$ and $4 c$ ). In two experiments each consisting of six replicates, basal concentrations of each of the three phospholipids were $6-10 \%$ higher in the presence of $R$-PIA. The effects of $R$-PIA on the hydrolysis of phospholipids were not prevented by the addition of $1 \mu \mathrm{M}$-forskolin (results not shown).

\section{DISCUSSION}

In this study we have shown that adenosine, via $A_{1}$ receptors, inhibits not only VIP-stimulated prolactin release and cyclic AMP accumulation but also TRHstimulated prolactin release and PI breakdown. In agreement with the data of Imai \& Gershengorn (1987) and Martin (1986), it was observed that TRH produced a rapid loss of PtdIns $4 P$ and PtdIn $(4,5) P_{2}$, with con- 

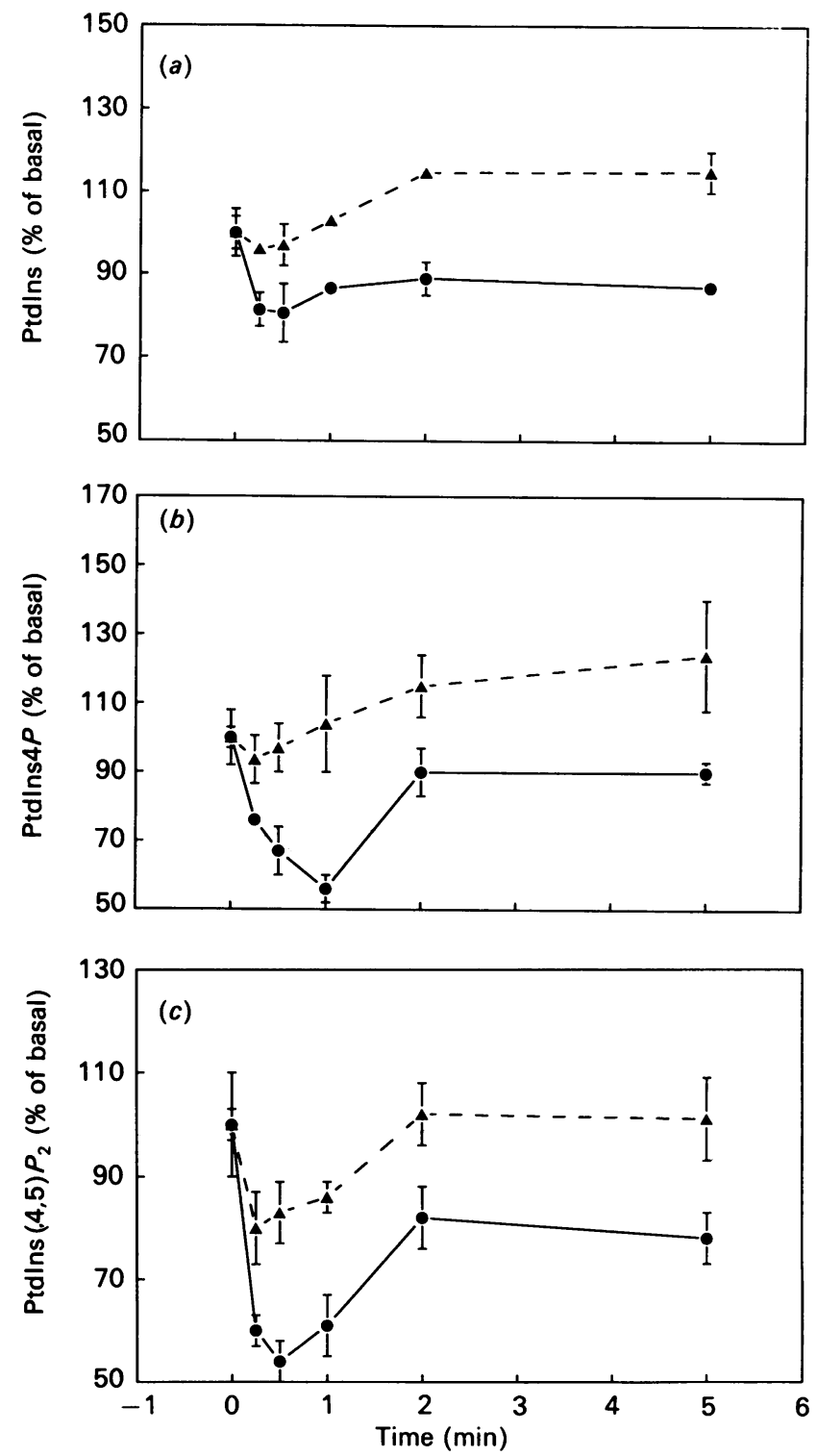

Fig. 4. Time course of inhibition of TRH-stimulated PI breakdown by $R$-PIA

Experiments were carried out in the presence of 3 units of ADA $/ \mathrm{ml}$. The effects of TRH $(1 \mu \mathrm{M})$ were assayed in the absence (O) and in the presence $(\Delta)$ of $10 \mu \mathrm{M}$ - $R$-PIA. Values for PI are presented as percentages of initial values with and without $R$-PIA. Initial values for all phosphoinositides were $5-10 \%$ higher in the presence of $R$-PIA. $(a)$ PtdIns; initial value was 5000 c.p.m. $/ 5 \times 10^{5}$ cells. (b) PtdIns4P; initial value was 900 e.p.m. $/ 5 \times 10^{5}$ cells. $(c)$ PtdIns $(4,5,) P_{2}$; initial value was 300 c.p.m. $/ 5 \times 10^{5}$ cells. All measurements represent the means of six determinations measured in duplicate.

comitant appearance of $\operatorname{Ins} P_{3}$ and $\operatorname{Ins} P_{2}$; this implies hydrolysis catalysed by phospolipase $C$. Thus, our results are consistent with the hypothesis that adenosine $A_{1}$ receptors are coupled to inhibition of phospholipase $C$. The adenosine analogues utilized in this study are not substrates for ADA, and are not actively taken up into the cell, but bind selectively to cell-surface receptors (Westermann \& Stock, 1970). The potency order of these analogues indicates that effects on both cyclic AMP and
PI metabolism are mediated through adenosine $A_{1}$ receptors.

Basal or VIP-stimulated cyclic AMP concentrations were increased by adding ADA, BW-A1433U or PTX, and were decreased by inhibiting ADA with EHNA (results not shown). All of these drugs may act to modify the amount or effect of endogenous adenosine released by $\mathrm{GH}_{3}$ cells in culture. In contrast with the effect of endogenous adenosine on cyclic AMP metabolism, no effect on basal or TRH-stimulated IP $x$ production could be detected in this study. This may be a consequence of the fact that adenosine and other agonists are more potent as inhibitors of cyclic AMP production than of IP $x$ generation. Evidence of autocrine inhibition by adenosine also has been observed in $\mathrm{GH}_{4} \mathrm{Cl}$ cells (Dorflinger \& Schonbrunn, 1985), adipocytes (Fain \& Wieser 1975; Schimmel et al., 1987) and hippocampal nerve terminals (Allgaier et al., 1987).

The efficacy of TRH was decreased in the presence of adenosine agonists, but the potency was unaltered. These findings rule out the possibility that adenosine interferes with TRH binding. Adenosine, $R$-PIA, CPA and NECA all inhibited TRH-stimulated IP $_{x}$ accumulation by about $50-60 \%$. A further inhibition by any of these drugs could not be elicited by increasing the doses or pretreating the cells with $R$-PIA. A maximal inhibition of $50 \%$ may reflect the presence of pools of $\operatorname{PtdIns}(4,5) P_{2}$ that are accessible to hydrolysis by TRH but differentially regulated by adenosine. Pools could co-exist in the same cell, or could be located in separate cells. $\mathrm{GH}_{3}$ cells have been recognized as functionally heterogeneous cells, composed of prolactin and growth-hormone secretors (Boockfor et al., 1985).

The curves relating $\mathrm{IP}_{x}$ production to adenosine agonist concentration were $U$-shaped. This is reminiscent of the dual effect of adenosine on adenylate cyclase when both $A_{1}$ and $A_{2}$ receptors are present. Since no $A_{2}-$ receptor-mediated response was observed, the explanation for this biphasic effect might be due to the fact that adenosine and its analogues, at concentrations exceeding $50 \mu \mathrm{M}$, selectively inhibit PtdIns kinase in membranes (Doctrow \& Lowenstein, 1987; O'Shea et al., 1987). However, PtdIns, PtdIns4 $P$ and PtdIns(4,5) $P_{2}$ all increased in the presence of $10 \mu \mathrm{M}-R$-PIA, suggesting that adenosine receptors are regulating an enzyme such as phospholipase C, which hydrolyses all three phosphoinositides (Wilson et al., 1984). This inhibition occurs at much lower nucleoside concentrations than are necessary to inhibit PtdIns kinase by a non-receptor-mediated process of dubious physiological significance.

We found that $R$-PIA inhibits TRH-stimulated $\operatorname{Ins} P_{3}$ accumulation at the earliest point measured, $15 \mathrm{~s}$, and infer that this results from a rapid inhibition of Ins $(1,4,5) P_{3}$ production. TRH-stimulated decreases in PtIns(4,5) $P_{2}$ were decreased by $R$-PIA at $15 \mathrm{~s}$, implying that hydrolysis is rapidly inhibited. Since adenosine is also an inhibitor of cyclic AMP accumulation in these cells, we considered the possibility that decreased cyclic AMP could be indirectly regulating the PI cycle. This seems unlikely, however, since the action of $R$-PIA of TRH-stimulated IP $_{x}$ production is unaltered in the presence of $1 \mu \mathrm{M}$-forskolin, a concentration which generated high concentrations of cyclic AMP even in the presence of $10 \mu \mathrm{M}$ - $R$-PIA. Inhibition of neurotransmitter release by $R$-PIA in hippocampal slices also persists in the presence of forskolin (Fredholm et al., 1987). In 
addition, PTX abolished the effect of $R$-PIA on cyclic AMP accumulation at a dose which did not completely abolish its effect on PI metabolism. Furthermore, agents known to inhibit cyclic AMP accumulation in $\mathrm{GH}_{3}$ cells (e.g. somatostatin and carbachol) have no effect on TRH-stimulated IP ${ }_{x}$ accumulation or phospholipid labelling (Yajima et al., 1986; Sutton \& Martin, 1982).

The transduction mechanisms of several receptors mediating PI breakdown appear to involve guaninenucleotide-regulatory $(G)$ proteins (for review see AbdelLatif, 1986). The name $G_{p}$ (p for phospholipid) has been coined to describe this protein (Berridge, 1987), although it appears that there may be more than one $G_{p}$ with different sensitivities to PTX. In $\mathrm{GH}_{3}$ cells, Ins $P_{3}$ release can be stimulated by GTP analogues, but TRHstimulated inositol phosphate accumulation is not sensitive to PTX (Martin et al., 1986; Wojcikiewicz et al.,

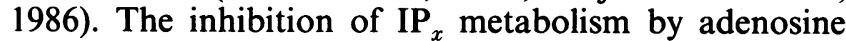
was only partially obviated by preincubating the cells with PTX at the same concentration $(50 \mathrm{ng} / \mathrm{ml}$ for $24 \mathrm{~h}$ ), which completely blocked inhibition of adenylate cyclase. This result suggests either that there are two $G$ proteins coupled to adenosine receptors, only one of which is sensitive to PTX at this concentration, or that the effect of adenosine on PI metabolism requires less functional G protein than is required to inhibit cyclic AMP production. In adipocytes, adenosine can inhibit both isoprenalineand phenylephrine-stimulated respiration, but these effects also differ in their sensitivity to PTX treatment (Schimmel et al., 1987). The inhibition of the PI-linked phenylephrine response by adenosine was blocked by PTX treatment only when all $G_{i}$ present was ADPribosylated by the toxin, whereas incomplete ADPribosylation of $G_{i}$ by PTX was sufficient to block adenosine inhibition of the adenylate cyclase-linked isoprenaline effect. A third example of differential sensitivity to PTX was described by Ashkenazi et al. (1987), who found that, in Chinese-hamster ovary cells transfected with $\mathbf{M}_{2}$ muscarinic receptors, a receptormediated IP $x$ response was less sensitive to PTX than was an adenylate cyclase response mediated by the same cholinergic receptor. Although differential sensitivity to PTX could be attributed to more efficient coupling of receptors to phospholipase $C$ than to adenylate cyclase, just the opposite order of coupling efficiency was observed in the transfected cells. These data are consistent with the possibility that different $G$ proteins may mediate the two responses. A G protein which appears to correspond to $\mathrm{G}_{\mathrm{i}}$ is ADP-ribosylated in $\mathrm{GH}_{3}$ cells (Wojcikiewicz et al., 1986; Martin et al., 1986; Yajima et al., 1986). This PTX substrate has been further resolved into two bands, corresponding closely to $G_{i}$ and $G_{0}$ (Zysk et al., 1986). Single receptors coupled to multiple effector systems have been noted in several tissues. For instance, in the cardiac atrium, both adenosine and acetylcholine inhibit adenylate cyclase and activate $\mathrm{K}^{+}$channels, possibly via the same receptors coupled to different $G$ proteins (Yatani et al., 1987). We have observed that in $\mathrm{GH}_{3}$ cells adenosine, carbachol and somatostatin all inhibit adenylate cyclase, but only adenosine inhibits IP $_{x}$ accumulation. These findings imply that components of $G_{i}$ involved in inhibition of adenylate cyclase ( $\alpha$ or $\beta-\gamma$ subunits) do not mediate the effect of adenosine on PI metabolism, or are differentially accessible to various receptors. Such observations support the notion that adenosine $A_{1}$ receptors communicate with more than one $G$ protein. Further- more, multiple species of G-protein $\alpha$ subunits are tightly complexed to adenosine $A_{1}$ receptors purified from bovine brain by affinity chromatography (R. Munshi \& J. Linden, unpublished work).

In a pituitary cell line, Lewis et al. (1986) found that somatostatin receptors are coupled to inhibition of adenylate cyclase and are coupled to $\mathrm{Ca}^{2+}$ channels by PTX-sensitive guanine nucleotide binding proteins. Studies in vitro of PI-hydrolysing phosphodiesterases from numerous sources have indicated that maximal activation of this enzyme requires concentrations of $\mathrm{Ca}^{2+}$ well above intracellular values (Irvine, 1982). TRH stimulation of $\mathrm{GH}_{3}$ cells (Martin et al., 1986) or addition of guanine nucleotide to permeabilized neutrophils (Bradford \& Rubin, 1986; Smith et al., 1986) sensitizes the enzyme to $\mathrm{Ca}^{2+}$ such that it becomes active at physiological concentrations. In agreement with Martin et al. (1986), we found that incubating cells for various times in EGTA decreases and ultimately abolishes the action of TRH. If $R$-PIA was producing its effect by decreasing $\left[\mathrm{Ca}^{2+}\right]_{\mathrm{i}}$ acutely, then treatment of cells with EGTA should mimic the action of $R$-PIA and prevent a further effect of $R$-PIA on IP ${ }_{x}$ contents. The ability of $R$-PIA to decrease IP $_{x}$ content was not diminished by short-term treatment with EGTA. Conversely, when $\left[\mathrm{Ca}^{2+}\right]_{\mathrm{i}}$ was elevated by $\mathrm{K}^{+}$depolarization the inhibition by $R$-PIA persisted, although the magnitude of the response was decreased from $50 \%$ to $28 \%$. IP $x$ accumulation measured in the presence of elevated $\left[\mathrm{Ca}^{2+}\right]_{i}$ produced by $140 \mathrm{mM}-$ $\mathrm{KCl}$ or maitotoxin was significantly decreased in the presence of $R$-PIA. These results suggest that the action of $R$-PIA is independent of both cyclic AMP and $\left[\mathrm{Ca}^{2+}\right]$. Moreover, preliminary data indicate that adenosine agonists inhibit TRH-stimulated $\mathrm{IP}_{x}$ production in $\mathrm{GH}_{3}$ cell membranes at concentrations similar to those observed to inhibit IP ${ }_{x}$ production in whole cells (T. M. Delahunty \& J. Linden, unpublished work). The effects of $R$-PIA on PI metabolism could result because $R$-PIA decreases the sensitivity of phospholipase $C$ to available $\left[\mathrm{Ca}^{2+}\right]_{\mathrm{i}}$, or because $R$-PIA inhibits phospholipase $\mathrm{C}$ by a $\mathrm{Ca}^{2+}$-independent mechanism.

This work was supported by grants HL-37942, AM-37490, AM-22125 and DK-38942 from the National Institutes of Health. J. L. is supported by an Established Investigator Award from the American Heart Association. We gratefully acknowledge numerous stimulating discussions with Dr. T. Rall (University of Virginia) and the helpful contributions of Dr. M. A. Sortino (University of Maryland School of Medicine) and Dr. R. D. Rice (University of Virginia).

\section{REFERENCES}

Abdel-Latif, A. A. (1986) Pharmacol. Rev. 38, 227-272

Allgaier, C., Hertting, G. \& Kügelgen, O. (1987) Br. J. Pharmacol. 90, 403-412

Anderson, J. M. \& Cronin, M. J. (1987) Life Sci. 41, 519-526

Ashkenazi, A., Winslow, J., Peralta, E., Peterson, G., Schimerlik, M., Capon, D. \& Ramachandran, J. (1987) Science 238, 672-674

Baudry, M., Evans, J. \& Lynch, G. (1986) Nature (London) 319, 329-331

Berridge, M. J. (1987) Annu. Rev. Biochem. 56, 159-193

Berridge, M. J., Dawson, R. M., Downes, C. P., Heslop, J. P. \& Irvine, R. F. (1983) Biochem. J. 212, 473-482

Biden, T., Peter-Reisch, B., Schlegel, W. \& Wollheim, C. (1987) J. Biol. Chem. 262, 3567-3571 
Boockfor, F. R., Hoeffler, J. P. \& Frawley, S. P. (1985) Endocrinology (Baltimore) 117, 418-420

Bradford, P. G. \& Rubin, R. (1986) Biochem. J. 239, 97-102

Brooker, G., Terasaki, W. L. \& Price, M. G. (1976) Science 194, 270-276

Canonico, P. L., Jarvis, W. D., Judd, A. M. \& MacLeod, R. M. (1986) J. Endocrinol. 110, 389-393

Clemo, H. F., Bourassa, A., Linden, J. \& Belardinelli, L. J. (1987) Pharmacol. Exp. Ther. 242, 478-484

Daluge, S. M. \& Leighton, H. J. (1986) European Patent 203721

Dean, N. \& Moyer, J. (1987) Biochem. J. 242, 361-366

Doctrow, S. R. \& Lowenstein, J. M. (1987) Biochem. Pharmacol. 36, 2255-2262

Dolphin, A. C. \& Prestwich, S. A. (1985) Nature (London) 316, $148-151$

Dorflinger, L. \& Schonbrunn, A. (1985) Endocrinology (Baltimore) 117, 2330-2338

Drummond, A. H., Bushfield, M. \& McPhee, C. (1984) Mol. Pharmacol. 25, 201-208

Dufy, B., McDermott, A. \& Barker, J. (1986) Biochem. Biophys. Res. Commun. 137, 388-396

Dunwiddie, T. V., Worth, T. S. \& Olsson, R. A. (1986) Naunyn-Schmiedebergs Arch. Pharmacol. 334, 77-85

Enjalbert, A., Sladeczek, F., Guillon, G., Bertrand, P. \& Shu, C. (1986) J. Biol. Chem. 261, 4071-4075

Fain, J. N. \& Wieser, P. B. (1975) J. Biol. Chem. 250, 1027-1031

Fredholm, B. B., Dunér-Engström, M., Fastbom, J., Jonzon, B., Lingren, E., Norstedt, C., Pedata, F. \& van der Ploeg, I. (1987) in Topics and Perspectives in Adenosine Research (Gerlach, E. \& Becker, B. F., eds.), pp. 509-520, SpringerVerlag, New York

Gourdji, D., Bataille, D., Vauclin, N., Groussele, D., Rosselin, G. \& Tixier-Vidal, A. (1979) FEBS Lett. 104, 165-169

Gourdji, D., Tougard, C. \& Tixier-Vidal, A. (1982) in Frontiers in Neuroendocrinology (Ganong, W. F. \& Martini, L., eds.), pp. 317-328, Raven Press, New York

Gustaffson, L., Hedquist, P. \& Fredholm, B. B. (1983) in Physiology and Pharmacology of Adenosine Derivatives (Daly, J. W., Kuroda, Y., Phillis, J. W., Shimizu, P. W. \& Ui, M., eds.), pp. 219-236, Raven Press, New York

Hill, S. J. \& Kendall, D. A. (1987) Br. J. Pharmacol. 91, 661-669

Hill, S. J. \& Kendall, D. A. (1988) J. Neurochem. 50, 497-502

Hollingsworth, E. B., De La Cruz, R. A. \& Daly, J. W. (1986)

Eur. J. Pharmacol. 122, 45-50

Imai, A. \& Gershengorn, M. (1987) Methods Enzymol. 141, $100-111$

Irvine, R. F. (1982) Cell Calcium 3, 295-309

Krebs, H. A. \& Henseleit, K. (1932) Hoppe-Seyler's Z. Physiol. Chem. 210, 33-66

Lewis, D., Weight, F. \& Luini, A. (1986) Proc. Natl. Acad. Sci. U.S.A. 83, 9035-9039

Linden, J., Vogel, S. \& Sperelakis, N. (1982) J. Pharmacol. Exp. Ther. 222, 383-388

Londos, C., Cooper, D. M. Wolff, J. (1980) Proc. Natl. Acad. Sci. U.S.A. 77, 2551-2554

Received 15 December 1987/21 March 1988; accepted 8 June 1988
Long, C. \& Stone, T. (1987) J. Pharm. Pharmacol. 39, 1010-1014

Marquadt, D. M. (1963) J. Soc. Ind. Appl. Math. 11, 437-444

Martin, T. F. (1983) J. Biol. Chem. 258, 14816-14833

Martin, T. F. (1986) Methods Enzymol. 124, 423-442

Martin, T. F., Lucas, D., Bajjalieh, S. \& Kowalchyk, J. (1986) J. Biol. Chem. 261, 2918-2929

Murayama, T. \& Ui, M. (1983) J. Biol. Chem. 258, 3319-3326

Murayama, T. \& Ui, M. (1987) J. Biol. Chem. 262, 1246312467

O'Shea, J. J., Suarez-Quian, C. A. \& Klausner, R. D. (1987) Biochem. Biophys. Res. Commun. 146, 561-567

Petcoff, D. \& Cooper, D. (1987) Eur. J. Pharmacol. 137, 269-271

Phillis, J. W. \& Wu, P. H. (1981) Prog. Neurobiol. 16, 187-239

Rubio, R. \& Bencherif, M. (1987) in Cardiac Electrophysiology and Pharmacology of Adenosine and ATP (Pelleg, A., ed.), pp. 77-93, Alan Liss, New York

Sattin, A. \& Rall, T. W. (1970) Mol. Pharmacol. 6, 13-23

Schimmel, R. J. (1986) Fed. Proc. Fed. Am. Soc. Exp. Biol. 45, 612-617

Schimmel, R. J., Elliott, M. E. \& Dehmel, V. C. (1987) Mol. Pharmacol. 32, 26-33

Schlegel, W., Wuarin, W., Wollheim, C. B. \& Zahnd, G. (1984) Cell Calcium 5, 223-236

Scott, R. H. \& Dolphin, A. C. (1987) in Topics and Perspectives in Adenosine Research (Gerlach, E. \& Becker, B. F., eds.), pp. 549-558, Springer-Verlag, New York

Smith, C. D., Cox, C. C. \& Snyderman, R. (1986) Science 232, 97-100

Stone, T. W. (1985) in Purines: Pharmacology and Physiological Roles (Stone, T. W., ed.), pp. 1-4, Macmillan, London

Sutton, C. \& Martin, T. (1982) Endocrinology (Baltimore) 110, $1273-1280$

Tabata, T. \& Ito, R. (1975) Comput. J. 18, 250-251

Takahashi, M., Tatsumi, M., Ohizumi, Y. \& Yasumoto, T. (1983) J. Biol. Chem. 258, 10944-10949

Van Calker, D., Muller, M. \& Hamprecht, B. (1979) J. Neurochem. 33, 999-1005

Westermann, E. \& Stock, K. (1970) in Adipose Tissue, Regulations and Metabolic Functions (Jeanrenaud, B. \& Hepp, D., eds.), pp. 47-54, Thieme, Stuttgart

Williams, M. (1987) Annu. Rev. Pharmacol. Toxicol. 27, 315-345

Wilson, D. B., Bross, T. E., Hofmann, S. L. \& Majerus, P. W. (1984) J. Biol. Chem. 259, 11718-11724

Wolff, J., Londos, C. \& Cooper, D. (1981) Adv. Cyclic Nucleotide Res. 14, 199-214

Wojcikiewicz, R., Kent, P. \& Fain, J. (1986) Biochem. Biophys. Res. Commun. 138, 1383-1389

Yajima, Y., Akita, Y. \& Saito, T. (1986) J. Biol. Chem. 261, 2684-2689

Yatani, A., Codina, J., Brown, A. M. \& Birnbaumer, L. (1987) Science 235, 207-211

Zysk, J. R., Pobiner, B. F., Hewlett, E. L., Garrison, J. C. \& Cronin, M. J. (1986) Endocrinol. Res. 12, 157-170 